This book is dedicated to

my loving grandmother, the late

Gilberte "Gibbie" Langis,

a.k.a. Memére,

who, I believe,

should be a candidate

for sainthood;

and

to my dear friend

\title{
Dr. John "Doc" Schultz
}

(Is August 1949-Io July I999),

a talented scientist and

undercover conservation officer,

who left us at a much too early age. 
THIS PAGE INTENTIONALLY LEFT BLANK 